\title{
PELATIHAN PELAKSANAAN PIJAT BAYI KEPADA IBU YANG MEMILIKI BAYI DI DESA PONDOK KEUMUNING, PONDOK KELAPA DAN PONDOK NIAS
}

https://doi.org/10.33024/jkpm.v4i6.4518

\author{
Fazdria $^{1 *}$, Nora Veri ${ }^{2}$, Cut Mutiah ${ }^{3}$, Dewita $^{4}$ \\ 1-4 Program Studi Kebidanan Langsa Poltekkes Kemenkes Aceh \\ Disubmit: 25 Juni 2021 Diterima: 08 Juli 2021 Diterbitkan: 01 Desember 2021 \\ Email Korespondensi: fadzria@poltekkesaceh.ac.id
}

\begin{abstract}
ABSTRAK
Di Indonesia, meskipun sejarah pemijatan berawal dari nenek moyang masa lampau, namun pijat bayi yang diperkenalkan bukanlah pijat tradisional yang dilakukan oleh dukun bayi atau dukun pijat yang pijatannya tidak aman. Pijat bayi yang dimasyarakatkan adalah pijat modern yang memadukan antara ilmiah (kesehatan), seni, dan kasih sayang. Pijat bayi akan membuat bayi tidur lebih lelap dan meningkatkan kosentrasi kesiagaan (alertness) atau kosentrasi. Hal ini disebabkan pijatan dapat mengubah gelombang otak. Pengubahan ini terjadi dengan cara menurunkan gelombang alpha dan peningkatan gelombang beta, serta tetha yang dapat dibuktikan dengan penggunaan EEG (electro enchephalogram). Tujuan kegiatan adalah meningkatkan pengetahuan dan keterampilan ibu dalam melakukan pijat bayi di Desa Pondok Kelapa, Pondok Nias dan Pondok Kemuning Kec. Langsa Baro Kota Langsa. Metode pengabdian yang digunakan dalam kegiatan ini adalah program pendidikan masyarakat melalui edukasi dan pelatihan pijat bayi pada ibu bayi dan balita. Hasil pengabdian kepada masyarakat yang telah dilakukan oleh Dosen Prodi D-III Kebidanan Langsa pada tanggal 30 September s/d 2 Oktober 2020 didapatkan hasil mayoritas peserta pengabdian kepada masyarakat memiliki pengetahuan yang baik tentang pijat bayi yaitu sebanyak 17 orang $(56,7 \%)$ dan mayoritas terampil dalam melakukan pijat bayi yaitu sebanyak 22 orang $(73,3 \%)$.
\end{abstract}

Kata Kunci : Pengetahuan, Keterampilan, Pijat Bayi

\begin{abstract}
In Indonesia, although the history of massage dates back to the ancestors of the past, but the baby massage introduced is not a traditional massage performed by a baby shaman or a massage shaman whose massage is not safe. A popularized baby massage is a modern massage that blends scientific (health), art, and compassion. Baby massage will make the baby sleep better and increase alertness or concentration. This is because massage can alter brain waves. This conversion occurs by lowering alpha waves and increasing beta waves, as well as tetha which can be proven by the use of EEG (electro enchephalogram). The purpose of the activity is to improve the knowledge and skills of mothers in performing baby massage in Pondok Kelapa Village, Pondok Nias and Pondok Kemuning Kec. Langsa Baro Langsa City. The method of devotion used in this
\end{abstract}


activity is a community education program through the education and training of baby massage in infants and toddler mothers. The results of community service that has been done by Lecturers of Prodi D-III Midwifery Langsa on September 30 to October 2, 2020 obtained the results of the majority of participants of community service have good knowledge about baby massage that is as many as 17 people (56.7\%) and the majority are skilled in performing baby massage that is as many as 22 people (73.3\%).

Keywords : Knowledge, Skills, Baby Massage

\section{PENDAHULUAN}

Tumbuh kembang pada bayi tidak terlepas dari konsep pertumbuhan dan perkembangan. Pertumbuhan adalah peningkatan ukuran bagian tubuh dari seorang individu yang masing-masing berbeda disertai dengan adanya perubahan fisik, sedangkan perkembangan adalah keterampilan, bertambah sempurnanya kemampuan dan fungsi tubuh yang lebih kompleks dalam kemampuan motorik kasar, motorik halus, bicara dan bahasa, serta sosialisasi dan kemandirian yang dimiliki individu untuk beradaptasi dengan lingkungan (Adriana 2013).

Usia 0 - 12 bulan merupakan masa kritis tumbuh kembang pada bayi, yang berlangsung secara singkat dan tidak akan terulang kembali. Bayi akan sangat peka terhadap lingkungan dan stimulasi baik pada proses pertumbuhan maupun perkembangannya (Kemenkes RI, 2009). Stimulasi yang baik dapat dilaksanakan oleh orang terdekat yakni orang tua. Stimulasi tersebut salah satunya adalah stimulasi taktil dalam bentul pijat bayi (Adriana 2013).

Masa bayi dianggap sebagai periode kritis dalam perkembangan kepribadian karena merupakan periode di mana dasar- dasar dari awal kehidupan (Yusuf, Rompas, and Babakal 2016). Masa bayi dikatakan sebagai Golden Age atau masa keemasan karena pada masa ini perkembangan otak berlangsung. Otak bayi mempunyai sifat plastisitas yaitu kemampuan susunan saraf untuk menyesuaikan diri terhadap perubahan atau kerusakan yang disebabkan oleh faktor eksternal dan internal, penyesuaian kemampuan saraf untuk regenerasi (Zero To Three n.d.). Bayi-bayi memiliki kesempatan untuk tumbuh dan berkembang dengan optimal pada masa keemasan di awal kehidupan mereka (Perry and Potter 2012).

Bayi dapat tumbuh dan berkembang dengan sehat jika kebutuhan dasarnya terpenuhi, yaitu asah, asih dan asuh. Kebutuhan asah disebut dengan kebutuhan stimulasi. Orang tua dapat memberikan stimulasi atau rangsangan yang baik untuk perkembangan potensinya secara maksimal. Tumbuh kembang sangat dipengaruhi oleh faktor nutrisi yang tercukupi, lingkungan keluarga yang mendukung, saah satunya adalah dengan melakukan pijat bayi. Berdasarkan teori maka pijat bayi sebaiknya dilakukan oleh orang yang terdekat dengan bayi dalam hal ini ibu bayi dalam rangka meningkatkan sentuhan fisik seperti belaian, pelukan dan pijatan lembut yang akan meningkatkan ikatan kasih sayang antara ibu dan bayi. Bayi yang dipijat akan mengalami peningkatan tonus nervus vagus (saraf otak ke 10) yang membuat kadar enzim penyerapan gastrin dan insulin meningkat sehingga penyerapan sari makanan menjadi lebih baik, penyerapan makanan yang lebih baik akan menyebabkan bayi cepat lapar dan karena itu bayi akan lebih sering menyusu (Roesli 2013). 
Pijat adalah terapi sentuh paling tua dan paling populer yang dikenal manusia. Pijat adalah seni perawatan kesehatan dan pengobatan yang telah dipraktekkan sejak berabad-abad silam, di seluruh dunia termasuk di Indonesia. Di Indonesia, seni pijat diajarkan secara turun temurun, tanpa diketahui secara jelas bagaimana pijat dan sentuhan dapat secara positif berpengaruh pada tubuh manusia (Roesli 2013).

Bayi dapat merasakan sensasi sentuhan atau raba sejak dini, sebab kulit adalah reseptor yang terluas dan telah dibuktikan bahwa bayi dapat merasakan sentuhan sejak masa janin atau ketika di dalam rahim ibu. Ujungujung saraf pada permukaan kulit akan bereaksi terhadap setiap sentuhan dan selanjutnya akan mengirimkan pesan ke otak melalu jaringan saraf yang berada di sumsum tulang belakang. Sentuhan juga akan merangsang peredaran darah sehingga oksigen segar akan lebih banyak dikirim ke otak dan seluruh tubuh, serta akan menambah energi (Roesli 2013).

Menurut (Roesli 2013), ahli neonatologi Indonesia, terapi sentuh (terutama pijat) menghasilkan perubahan fisilogis (berkaitan dengan zat hidup seperti organ, jaringan atau sel) yang menguntungkan dan dapat diukur secara ilmiah melalui pengukuran kadar cortisol ludah, kadar cortisol plasma secara Radioimunoassay, kadar hormone stress (Chatecholamine) air seni dan pemerikasaan EEG (Electro Enchepalogram).

Pemijatan juga mengoptimalkan tumbuh kembang bayi dengan resiko tinggi, yakni bayi-bayi yang dalam proses kehamilan dan kelahirannya mempunyai faktor-faktor resiko yang dapat mengganggu tumbuh kembangnya. Misalnya, berat lahir kurang dari 2000 gram. Pijat bayi dapat digolongkan sebagai aplikasi stimulasi sentuhan karena dalam pijat bayi terdapat unsur sentuhan berupa kasih sayang, perhatian, suara, pandangan mata, gerakan dan pijatan. Stimulasi ini akan merangsang perkembangan struktur dan fungsi sel- sel otak (Roesli 2013).

Masalahnya, sampai saat ini masih ada orang tua yang menganggap pijat bukanlah sebuah bentuk terapi ilmiah sekaligus alamiah bagi bayi. Sebagian ibu berpendapat pijat hanya perlu dilakukan ketika sikecil mengalami sakit flu dan masuk angin. Namun fakta sejarah menyebutkan bahwa pijat merupakan metode terapi sentuh tertua di Indonesia. Para ahli kesehatan menemukan pijatan dengan teknik yang tepat kepada anak dan balita, bisa dilakukan saat mereka dalam kondisi kesehatan yang baik (Maharani 2009).

Pijat bayi mempunyai banyak manfaat, diantaranya dapat meningkatkan berat badan bayi, mengurangi kebiasaan menangis, membuat bayi tertidur lebih lelap, memudahkan buang air besar serta mengurangi angka kesakitan pada bayi (Maharani 2009; Roesli 2013).

Maka dari itu, penulis tertarik untuk melakukan kegiatan pengabdian kepada masyarakat dengan judul "Pelatihan Pelaksanaan Pijat Bayi Kepada Ibu Yang Memiliki Bayi Di Desa Pondok Keumuning, Pondok Kelapa dan Pondok Nias Tahun 2020".

\section{MASALAH}

Permasalahan yang mendasari program pengabdian kepada masyarakat ini adalah kurangnya pemahaman dan keterampilan ibu bayi dan balita dalam melakukan pijat bayi. Solusi yang ditawarkan untuk pemecahan masalah adalah cara melakukan pijat bayi untuk meningkatkan kualitas kesehatan bayi dan balita di Desa Pondok Kelapa, Pondok Keumuning dan Pondok Nias Tahun 2020. Secara jelas diuraikan pada skema berikut ini : 
Secara jelas diuraikan pada skema berikut ini :

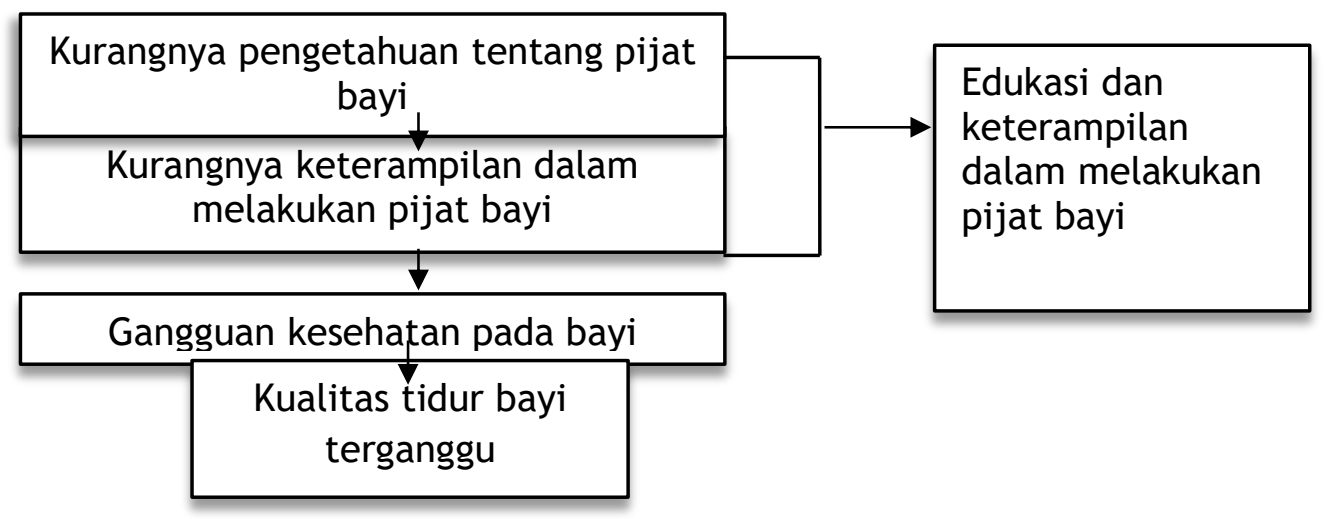

\section{Skema \\ Kerangka Pemecahan Masalah}

Lokasi kegiatan dilakukan di Polindes Pondok Kelapa. Peta lokasi PKM tergambar dibawah ini :

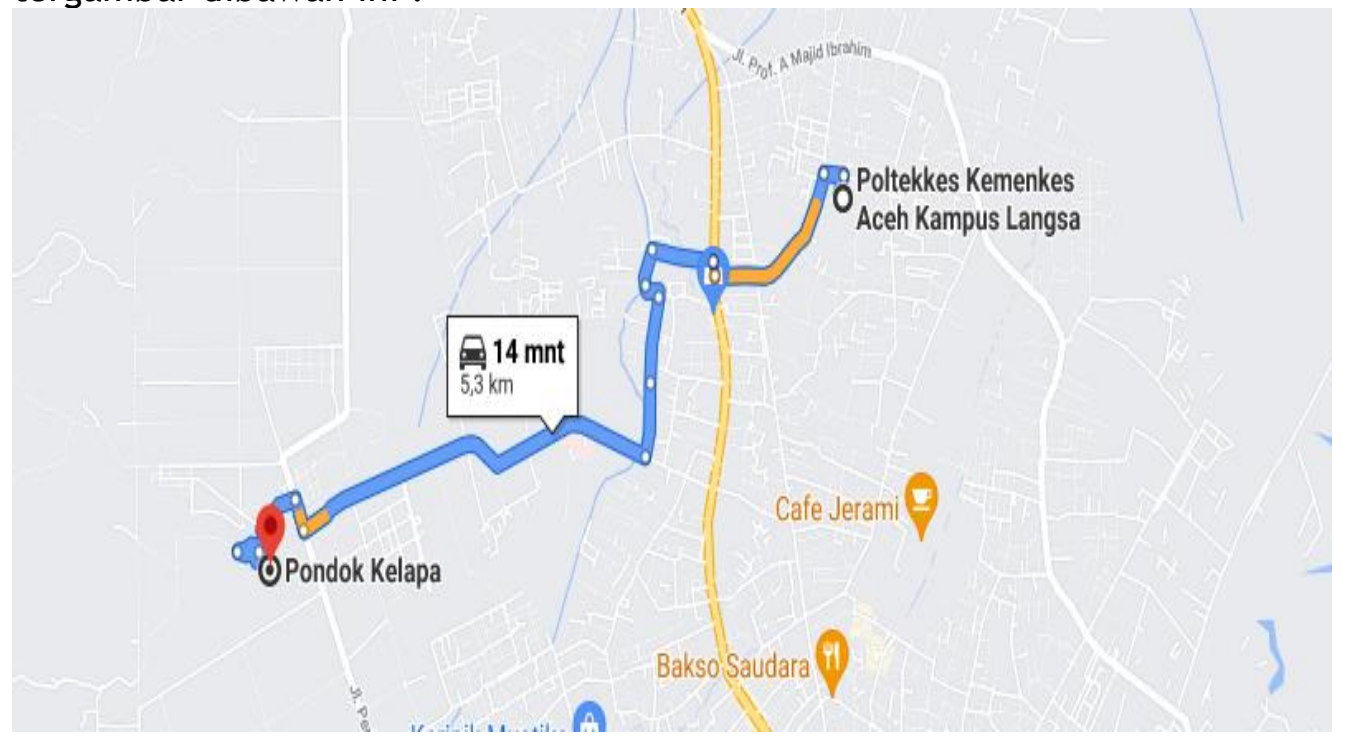

Gambar 2.1

Peta Lokasi Kegiatan Pengabdian Kepada Masyarakat

\section{METODE}

Metode atau bentuk kegiatan yang digunakan adalah program pendidikan masyarakat melalui edukasi tentang pijat bayi dan cara melakukan pijat bayi pada ibu yang memiliki bayi di Desa Pondok Kelapa, Pondok Keumuning dan Pondok Nias yang berjumlah 30 orang.
a. Tahap Persiapan
Tahap persiapan kegiatan adalah pembuatan SAP, POA, koordinasi dengan Pimpinan Puskesmas Langsa Lama, pembuatan leaflet dan media presentasi.
b. Tahap Pelaksanaan
Kegiatan pengabdian dilakukan selama tiga hari dari tanggal 30 September s/d 2 Oktober 2020 di Polindes Pondok Kelapa.


c. Evaluasi

1) Indikator Input

Indikator input terdiri dari dana, sumber daya manusia dan sarana/prasarana yang dipergunakan dalam menjalankan kegiatan. Evaluasi/penilaian atas capaian kinerja input dilakukan dengan melihat ketersediaan sumber daya manusia yang terlibat dan ketersediaan sarana/prasarana. Pada pelaksanaan ini, dengan adanya sumber dana yang memadai yang bersumber dari DIPA Poltekkes Aceh, adanya SDM dengan kualifikasi yag sesuai yaitu dengan latar pendidikan magister kesehatan dan kebidanan, serta ditunjang dengan sarana dan prasarana yang tersedia yaitu Polindes Pondok Kelapa, maka kegiatan pengabdian kepada masyarakat ini dapat dilaksanakan sesuai dengan jadwal.

2) Indikator Proses

Indikator proses ini terdiri dari :

a) Metoda

Kesesuaian penggunaan metode/proses/langkah kegiatan dalam mencapai tujuan/sasaran yaitu dalam pelaksanaan kegiatan pengabdian kepada masyarakat ini menggunakan metode edukasi tentang pijat bayi dan cara melakukan pijat bayi pada ibu yang memiliki bayi.

b) Waktu pelaksanaan :

Kesesuaian waktu pelaksanaan dari rencana : Pelaksanaan kegiatan dilakukan sesuai dengan jadwal.

c) Keterpaduan

Keterkaitan dan keterpaduan rencana kerja dengan pelaksanaan : Tema kegiatan PKM ini dipilih karena melihat masalah yang terjadi di lapangan. Pelaksaan kegiatan dilakukan sesuai dengan rencana kerja yang telah disusun.

d) Kalender Harian

Pelaksanaan kegiatan didokumentasikan melalui foto, daftar hadir dan lembar kuesioner yang telah diisi oleh peserta pengabdian masyarakat.

3) Indikator Ouput

Evaluasi/Penilaian atas capaian kinerja output dilakukan dengan melihat output dari kegiatan yang tercantum dalam Indikator Kinerja

Indikator output ini terdiri dari :

1) Mayoritas ibu bayi memiliki pengetahuan dan keterampilan yang baik tentang pijat bayi serta cara mengaplikasikan teknik pijat bayi tersebut.

2) Kehadiran peserta mencapai $100 \%$

3) Minat peserta tinggi karena seluruh peserta pengabmas (ibu bayi) dapat mengaplikasikan teknik yang diajarkan oleh penyaji secara baik.

4) Peserta berharap akan ada pelatihan-pelatihan lain yang dapat meningkatkan pengetahuan dan keterampilan pada ibu yag memiliki bayi. 


\section{HASIL DAN PEMBAHASAN}

Berdasarkan hasil edukasi yang diberikan kepada ibu yang memiliki bayi maka didapatkan hasil :

Tabel 4.1

Distribusi Frekuensi Pengetahuan Ibu Bayi dan Balita Tentang Pijat Bayi Di Desa Pondok Kelapa, Pondok Keumuning dan Pondok Nias Tahun 2020

\begin{tabular}{ccc}
\hline Pengetahuan & $\mathbf{f}$ & $\mathbf{( \% )}$ \\
\hline Baik & 17 & 56,7 \\
\hline Cukup & 6 & 20 \\
\hline Kurang & 7 & 23,3 \\
\hline Total & 30 & 100 \\
\hline
\end{tabular}

Berdasarkan tabel 4.1 distribusi frekuensi jawaban responden berdasarkan kuesioner pengetahuan tentang pijat bayi mayoritas berpengetahuan baik sebanyak 17 orang $(56,7 \%)$, berpengetahuan cukup sebanyak 6 orang (20\%) dan berpengetahuan kurang sebanyak 7 orang $(23,3 \%)$.

Tabel 4.2

Distribusi Frekuensi Keterampilan Ibu Bayi dan Balita Dalam Melakukan Pijat Bayi Di Desa Pondok Kelapa, Pondok Keumuning dan Pondok Nias Tahun 2020

\begin{tabular}{ccc}
\hline Keterampilan & $\mathbf{f}$ & $\mathbf{( \% )}$ \\
\hline Terampil & 22 & 73,3 \\
\hline Kurang Terampil & 8 & 26,7 \\
\hline Total & 30 & 100 \\
\hline
\end{tabular}

Berdasarkan tabel 4.2 keterampilan ibu bayi dan balita dalam melakukan pijat bayi mayoritas terampil yaitu sebanyak 22 orang $(73,3 \%)$ dan kurang terampil sebanyak 8 orang $(26,7 \%)$.

Berdasarkan hasil yang diperoleh, maka didapati mayoritas ibu yang memiliki bayi dan balita memiliki pengetahuan yang baik tentang pijat bayi dan juga terampil dalam melakukan pijat bayi. Pada saat edukasi dilakukan, ibu bayi dan balita di Desa Pondok Kelapa, Pondok Keumuning dan Pondok Nias antusias menyimak materi yang disajikan dan aktif bertanya mengenai hal-hal yang tidak dimengerti. Upaya edukasi yang telah dilakukan terbukti menambah pengetahuan ibu yang memilki bayi dan balita tentang pijat bayi guna menjaga kesehatan pada anaknya. Hal ini sesuai dengan teori yang mengemukakan bahwa pengetahuan adalah kesan didalam pikiran manusia sebagai hasil penggunaan pancainderanya. Pengetahuan sangat berbeda dengan kepercayaan (beliefs), takhayul (supertition), dan peneranganpenerangan yang keliru (misinformation). Pengetahuan adalah segala apa yang diketahui berdasarkan pengalaman yang didapatkan oleh setiap manusia. Pengetahuan juga merupakan, hasil mengingat suatu hal, termasuk mengingat kembali kejadian yang pernah dialami baik secara sengaja maupun tidak disengaja dan ini terjadi setelah orang melakukan kontak atau pengamatan terhadap suatu objek tertentu. Perilaku yang didasari oleh 
pengetahuan akan lebih lama daripada perilaku yang tidak didasari oleh pengetahuan (misalnya perilaku karena paksaan atau adanya aturan wajib) (Mubarak 2012).

Pengetahuan didapatkan secara formal maupun informal. Pengetahuan formal ini diperoleh dari pendidikan sekolah, sedangkan pendidikan informal diperoleh dari luar sekolah seperti lingkungan keluarga, orang lain dalam pergaulan sehari-hari dan dapat juga diperoleh dari media informasi yaitu media cetak, seperti buku, majalah, leaflet dan media elektronik seperti televisi, radio dan internet.

Pengetahuan pada dasarnya terdiri dari sejumlah fakta dan teori yang memungkinkan seseorang untuk dapat memecahkan masalah yang dihadapinya. Pengetahuan tersebut diperoleh dari pengetahuan langsung maupun melalui pengalaman orang lain. Pengetahuan atau kognitif maupun prediksi yang sangat penting dalam membentuk tindakan seseorang.Pengetahuan seseorang dipengaruhi oleh banyak faktor yaitu pendidikan, umur, paritas, semua faktor ini saling terkait, sehingga memungkinkan seseorang untuk berpikir tentang penyelesaian masalah atau hal yang dihadapinya.

Pijat bayi merupakan terapi sentuh kontak langsung dengan tubuh yang dapat memberikan rasa aman dan nyaman pada bayi. Sentuhan dan pelukan dari seorang ibu adalah kebutuhan dasar bayi. Jika pijat bayi dilakukan secara teratur akan meningkatkan hormon katekolamin (epinefrin dan norepinefrin) yang dapat memicu stimulasi tumbuh kembang karena dapat meningkatkan nafsu makan, meningkatkan berat badan, dan merangsang perkembangan struktur maupun fungsi otak (Riksani 2012).

Pijat bayi sangat penting bagi kesehatan bayi. Terutama apabila dilakukan oleh orang tua sendiri. Sehingga peran orangtua sangat dibutuhkan dalam memberikan pijatan pada bayi. Agar menciptakan komunikasi antara orang tua dan bayi melalui sentuhan pijatan yang mengandung unsur kasih sayang, suara, kontak mata, dan gerakan. Pijat pada bayi dapat melibatkan keluarga-keluarga terdekat untuk mendekatkan hubungan emosional, misalnya ayah, nenek, kakek. Naluri seorang bayi dapat merespon sentuhan dari ibunya sebagai ungkapan rasa cinta, perlindungan, dan perhatian (Roesli 2013).

Ditengah-tengah masyarakat berkembang ini, masyarakat di Indonesia masih memanfaatkan pelayanan kesehatan tradisional khususnya pijat bayi ke dukun bayi sebanyak 30,4 \% (BPPK, 2013). Pijat bayi ke dukun sudah menjadi tradisi yang turun menurun. Faktor lingkungan sosial sangat berkaitan dengan budaya atau tradisi serta kuatnya pengaruh tokoh masyarakat setempat. Keyakinan keluarga yang dahulu sering memijatkan bayinya ke dukun bayi dapat mempengaruhi perilaku orang tua yang kurang dalam melakukan pijat bayi. Faktor lingkungan sosial akan mempengaruhi pembentuk sikap dan persepsi dengan menganggap pergi ke dukun bayi adalah hal baik serta dukun bayi masih dianggap sebagai bagian penting dalam kultur masyarakat setempat. Pijat bayi jarang menyebabkan efek samping. Namun, bila pemijatan dilakukan terlalu dalam, dapat menyebabkan perdarahan pada organ vital seperti hati karena adanya pembentukan penumpukan darah (Subakti 2008).

Salah satu sentuhan yang dikenal memberikan banyak manfaat adalah pijat bayi. Pijat bayi disebut juga terapi sentuh, dikatakan terapi sentuh karena melalui pijat bayi akan terjadi komunikasi yang nyaman dan aman antara ibu dan buah hatinya. Sentuhan ibu kepada bayinya dengan 
memberikan pijatan-pijatan ringan segera setelah kelahiran merupakan suatu kontak tubuh kelanjutan yang diperlukan bayi untuk mempertahankan rasa aman dan nyaman (Riksani 2012).

Secara tidak sadar, kita telah melakukan pijatan pada bayi seusai memandikan, yakni ketika mengolesi tubuh si kecil dengan minyak telon. Sentuhan -sentuhan itu merupakan hal yang disukai karena memberikan rasa nyaman bagi bayi. Secara ilmiah, pijatan memberi stimulus pada hormon di dalam tubuh, satu substansi yang mengatur fungsi fungsi sperti nafsu makan, tidur, ingatan dan belajar, pengatur temperatur, mood, perilaku, fungsi pembuluh darah, kontraksi otot, pengatur sistem endokrin dan depresi (Prasetyono 2009).

Banyak diantara ibu, ayah atau anggota keluarga lain belum mengetahui manfaat dari pijat bayi. Mereka beranggapan bahwa pijat bayi hanya dilakukan sebagai terapi untuk menyembuhkan penyakit. Pada kenyataannya, pijatan yang dilakukan ibu, ayah atau anggota keluarga lain merupakan pijatan terbaik karena terbukti dapat menghasilkan perubahan fisiologis yang menguntungkan terutama bisa memenuhi kebutuhan kasih sayang. Sentuhan yang diberikan oleh ibu selama pemijatan akan direspon oleh bayi sebagai bentuk perlindungan, kasih sayang, perhatian dan ungkapan cinta yang tulus (Riksani 2012).

Masih banyak juga orangtua yang belum mengerti tentang pijat bayi, sebagian dari mereka beranggapan bahwa pijat bayi dilakukan hanya pada bayi yang sakit serta dilakukan oleh dukun atau tenaga medis yang menguasai pijat bayi. Hal ini tidak sepenuhnya salah, melalui teknik tertentu, pijat bayi diyakini mampu mengatasi kolik sementara, sembelit dan bayi rewel. Namun, manfaat utama dari pijat bayi adalah membantu mengoptimalkan tumbuh kembang bayi.Kurangnya informasi yang tepat tentang perkembangan terbaru pijat bayi di masyarakat juga membuat orangtua takut menyentuh bayinya (Marsaoly 2018).

Manfaat lain dari pijat bayi juga memperbaiki sistem imunitas si kecil serta menambah jumlah produksi darah putih yang membuat menjadi lebih sehat. Pijat akan menstimulasi enzim - enzim yang ada di perutnya sehingga penyerapan nutrisi dalam tubuhnya lebih optimal. Selain itu, memijat si kecil secara teratur dapat memberikan manfaat untuk mempengaruhi rangsangan saraf dan kulit serta memproduksi hormon - hormon yang berpengaruh dalam meningkatkan nafsu makan si kecil, seperti hormon gastrin dan insulin yang berperan penting dalam proses penyerapan makanan. Pada bayi yang dipijat, produksi kedua hormon ini meningkat sehingga penyerapan nafsu makan meingkat. Nafsu makan yang meningkat kemudian akan membuat berat badannya naik (Roesli 2013).

Pijat dapat merangsang keluarnya hormon endorphin yang bisa menurunkan nyeri, sehingga membuat bayi merasa lebih tenang dan mengurangi frekuensi menangis dengan demikian pijatan juga meningkatkan kualitas dan kuantitas tidur bayi.Pijat telah dipraktekkan hampir diseluruh dunia, seni pijat telah diajarkan secara turun temurun walaupun tidak diketahui jelas bagaimana pijat dan sentuhan dapat memberikan efek positif pada tubuh manusia (Prasetyono 2009).

Manfaat untuk membantu sistem kekebalan tubuh bayi, membantu sistem kekebalan tubuh bayi, membantu melatih relaksasi, membuat tidur lelap, serta membantu pengaturan sistem pencernaan dan penapasan. Pemijatan juga mengoptimalkan tumbuh kembang bayi dengan resiko tinggi, yakni bayi-bayi yang dalam proses kehamilan dan kelahirannya mempunyai 
faktor-faktor resiko yang dapat mengganggu tumbuh kembangnya, misalnya berat lahir kurang dari 2000 Gram, tidak langsung menangis, biru, kadar bilirubin tinggi, sering kejang,dan mengidap penyakit atau gangguan kesehatan lainnya (Roesli 2013).

Akan tetapi pijat bayi yang dilakukan tidak sesuai dengan langkah langkah dan teknik yang tepat dapat menyebabkan kesakitan dan ketidaknyamanan pada bayi terutama pada bayi yang baru diimunisasi dengan demikian pemijatan pada bayi harus dilakukan oleh orang yang terlatih dan tahu tentang teknik dalam melakukan pemijatan pada bayi.

Agar diperoleh hasil yang optimal dalam pemijatan pada bayi, maka diperlukan dasar pengetahuan yang cukup pada ibu untuk melakukan pijat bayi, pijat bayi merupakan usaha yang positif untuk memperoleh kondisi yang maksimal pada masa bayi tersebut karena merangsang semua kerja sistem sensorik dan motorik.

Faktor yang mempengaruhi penatalaksaaan pijat bayi oleh ibu meliputi faktor internal dan eksternal. Faktor internal diantaranya pendidkan, dengan pendidikan yang tinggi ibu akan lebih paham tentang kesehatan bayinya. Faktor pengetahuan dengan pengetahuan ibu yang luas akan berpengaruh pula pada keinginan ibu untuk melakukan pijat bayi, selain itu ada pula faktor pekerjaan, sikap dan presepsi yang dapat mempengaruhi ibu untuk melakukan pijat bayi. Faktor eksternal meliputi faktor kebudayaan, ibu melakukan pijat bayi kepada bayinya dikarenakan sudah menjadi sebuah kepercayaan dan tradisi tersendiri, faktor lingkungan sosial serta dukungan keluarga juga berpengaruh pada minat ibu untuk melakukan pijat bayi (Pertiwi, Lestari, and Pawiono 2014).

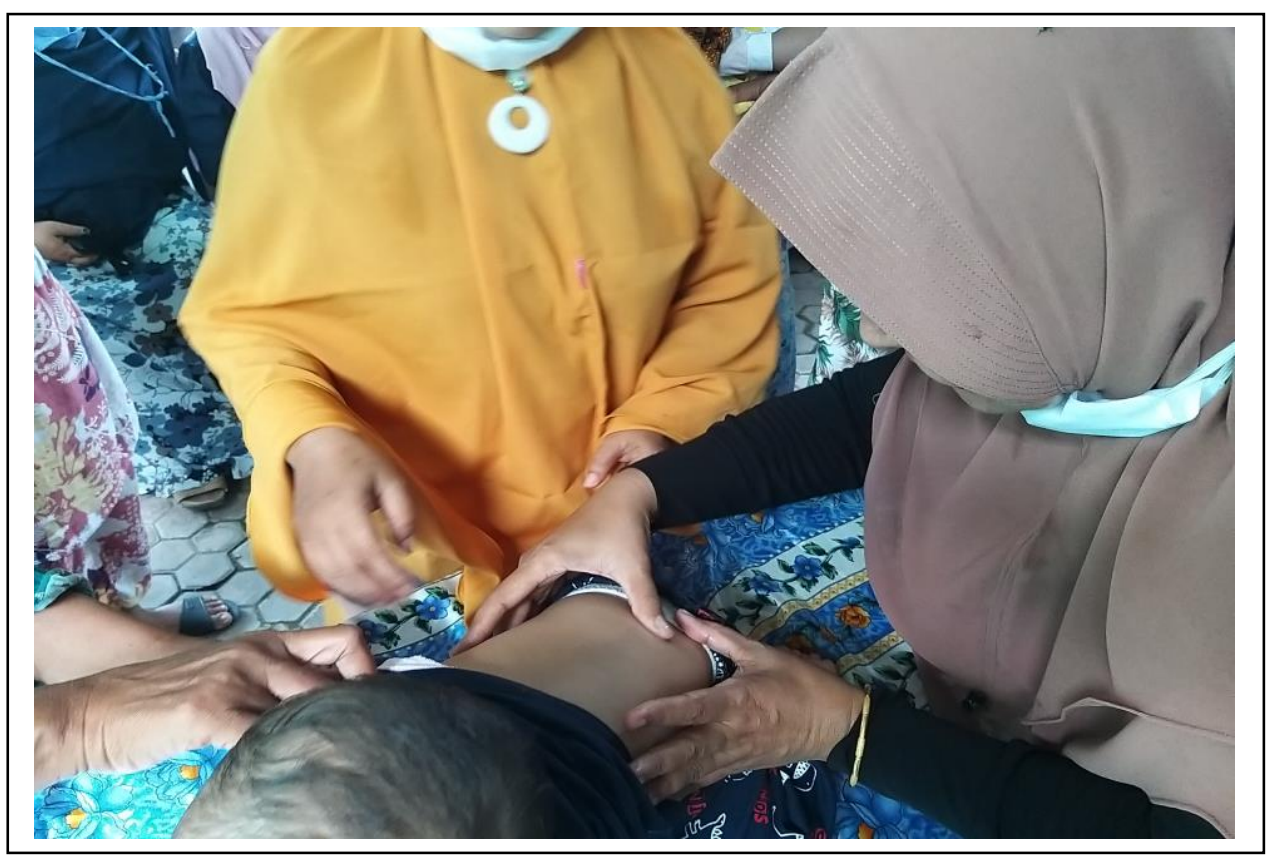

Gambar 2.1 Foto Kegiatan PKM 


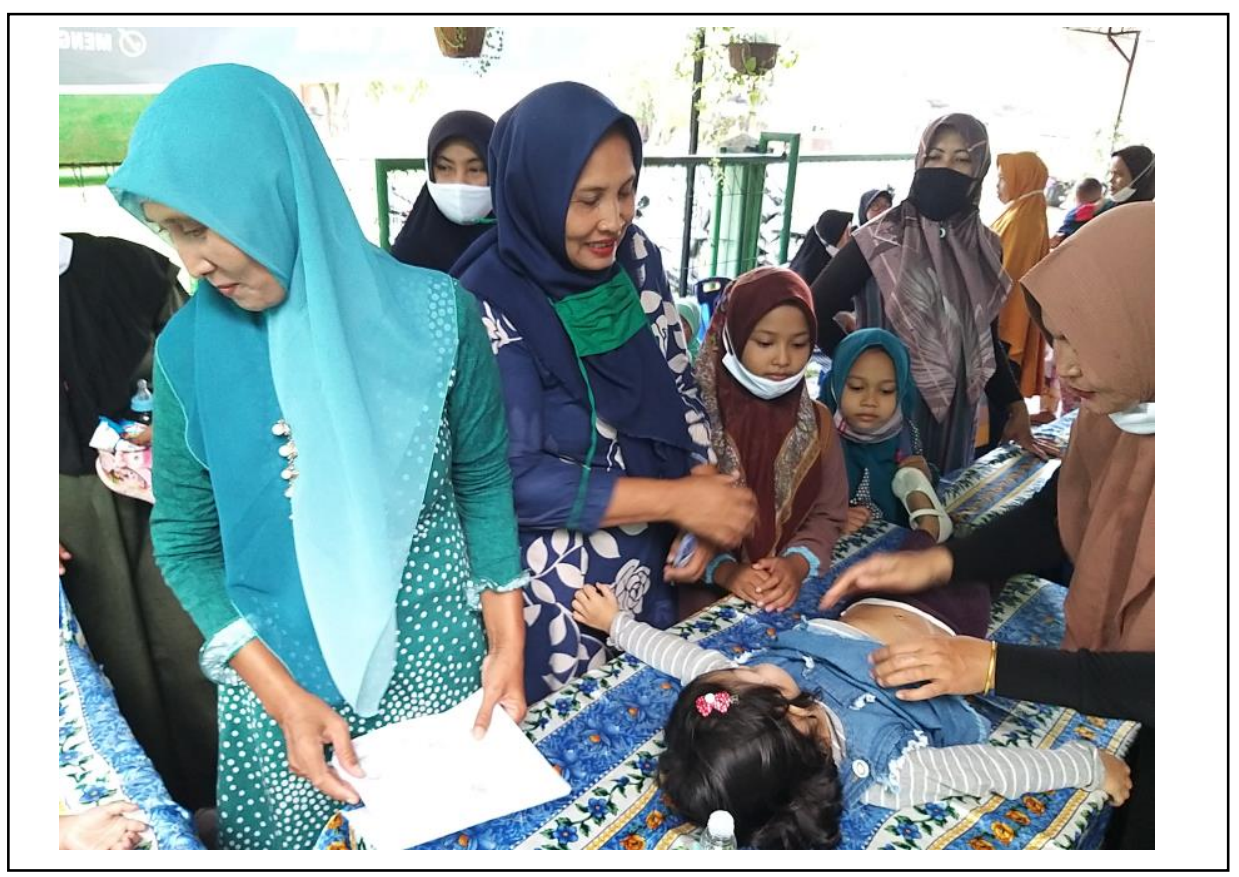

Gambar 2.2 Foto Kegiatan PKM

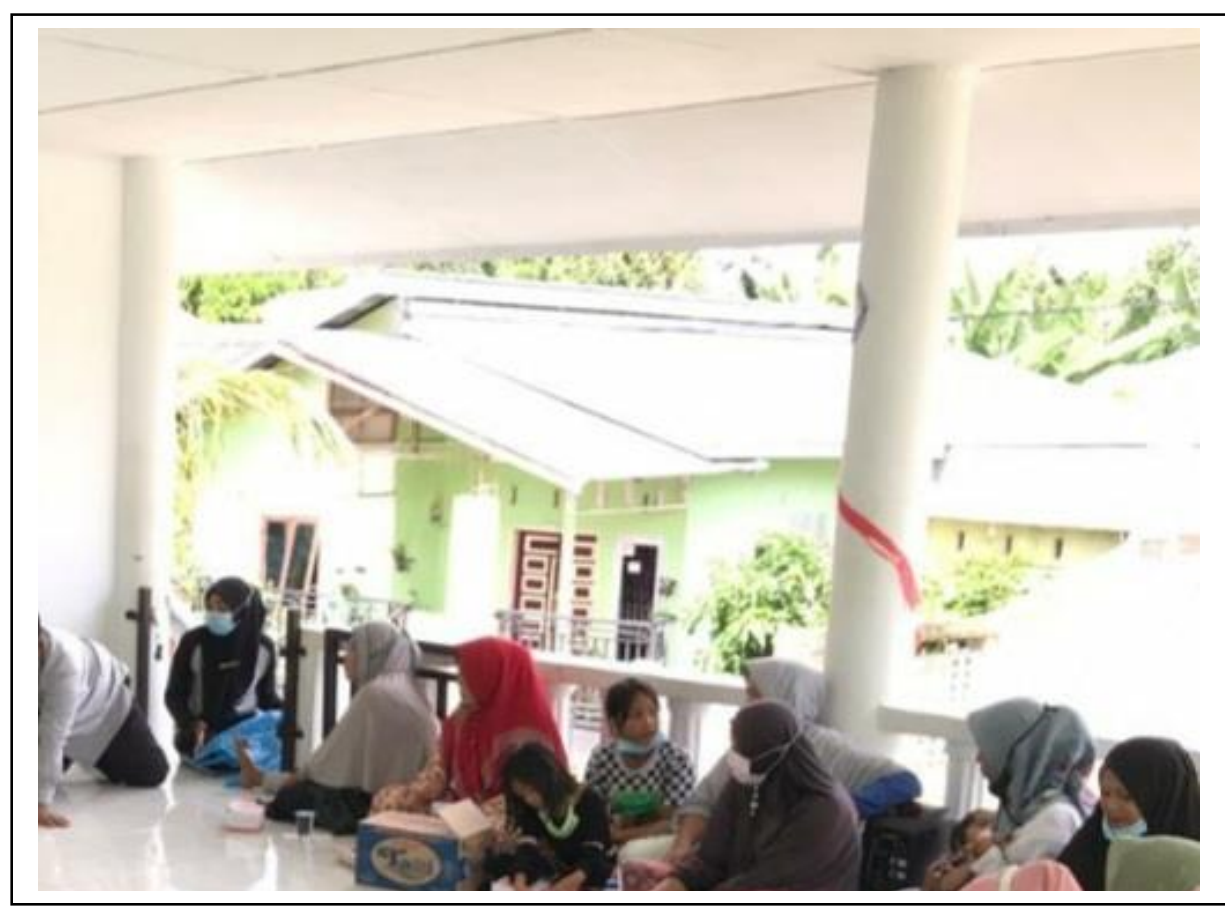

Gambar 2.3 Foto Kegiatan PKM

\section{KESIMPULAN}

Adanya peningkatan pengetahuan dan keterampilan setelah dilakukan edukasi tentang pijat bayi yang berarti bahwa kegiatan edukasi yang dilakukan secara optimal oleh Dosen Prodi Kebidanan Langsa sangat bermanfaat bagi ibu yang memiliki bayi yang berada di Desa Desa Pondok Kelapa, Pondok Keumuning dan Pondok Nias. 


\section{DAFTAR PUSTAKA}

Adriana. (2013). Tumbuh Kembang Dan Terapi Bermain Pada Anak. Jakarta: Salemba Medika.

Maharani, S. (2009). Pijat Dan Senam Sehat Untuk Bayi. Yogyakarta: Kata Hati.

Marsaoly, S. (2018). “Pengetahuan Dan Sikap Ibu Tentang Perilaku Pijat Bayi Di Posyandu Kelurahan Maliaro Kota Ternate Tengah." 8(0451).

Mubarak, I. W. (2012). Ilmu Kesehatan Masyarakat Konsep Dan Aplikasi Dalam Kebidanan. Jakarta: Salemba Medika.

Perry, A. G., Patricia A. P. (2012). Fundamental of Nursing. Jakarta: Salemba Medika.

Pertiwi, D., Lestari. R.H., Pawiono. (2014). “Pelaksanaan Pijat Bayi Usia 3 Bulan - 36 Bulan Di Desa Banjaragung Kecamatan Bareng Kabupaten Jombang."

Prasetyono, D. (2009). Teknik-Teknik Tepat Memijat Bayi Sendiri. Yogyakarta: Diva Press.

Riksani, R. (2012). Cara Mudah Dan Aman Pijat Bayi. Jakarta: Niaga Swadaya.

Roesli, U. (2013). Pedoman Pijat Bayi. Jakarta: Trubus Agriwidya.

Subakti, Y. (2008). Keajaiban Pijat Bayi Dan Balita. Jakarta: PT. Wahyu Media.

Yusuf, Y., S. Rompas., A. Babakal. (2016). "Pengaruh Pendidikan Kesehatan Dengan Pendekatan Modelling Terhadap Pengetahuan Ibu Dalam Menstimulasi Tumbuh Kembang Bayi 0-6 Bulan Di Posyandu Wilayah Kerja Puskesmas Tomalou Kota Tidore Kepulauan." Jurnal Keperawatan UNSRAT 4(1):108488.

Zero To Three, . n.d. "Behavior and Development." Washington : National Center For Infants, Toodlers and Families. 